\title{
MODYFIKACJA SUBSTRATÓW STALYCH PRZEZ KONTROLOWANĄ ADSORPCJĘ MAKROJONÓW
}

\author{
MODIFICATION OF SOLID SUBSTRATES BY \\ CONTROLLED ADSORPTION OF MACROIONS
}

Maria Morga*, Zbigniew Adamczyk

Jerzy Haber Institute of Catalysis and Surface Chemistry

Polish Academy of Sciences,

Niezapominajek 8, 30-239 Krakow, Poland

*e-mail: maria.morga@ikifp.edu.pl

\author{
Abstract \\ Abbreviations and symbols \\ 1. Introduction \\ 2. Experimental methods \\ 3. Bulk macroion characteristics \\ 4. Macroion adsorption - monolayer characteristics \\ 5. Macroion layer stability \\ 6. Conclusions \\ Acknowledgments \\ References
}


Dr inż. Maria Morga - doktor nauk chemicznych od 2014 roku. Adiunkt w Instytucie Katalizy i Fizykochemii Powierzchni im. Jerzego Habera Polskiej Akademii Nauk. Absolwentka jednolitych studiów magisterskich Politechniki Krakowskiej, wydziału Inżynierii i Technologii Chemicznej, absolwentka studiów podyplomowych wydziału Inżynierii Materiałowej i Ceramiki (Biomateriały - Materiały dla Medycyny). Kierownik projektu NCN Sonata o tematyce z zakresu wytwarzania monowarstw i multiwarstw nanocząstek i makrojonów: polielektrolitów, polipeptydów na powierzchniach granicznych ciało stałe-ciecz, określania kinetyki adsorpcji makrojonów na powierzchniach stałych oraz badaniu stabilności monowarstw makrojonów w zależności od warunków środowiska. Współautorka 35 publikacji oraz 1 patentu. Wykonawca 8 projektów naukowych NCN i Funduszy Strukturalnych UE. Szerokie doświadczenie w prowadzeniu badań z zastosowaniem technik mikroelektroforezy kapilarnej oraz metody DLS do charakterystyki makrojonów w objętości oraz w prowadzeniu badań nad charakterystyką multiwarstw nanocząstek na powierzchni ciał stałych i określaniu właściwości fizykochemicznych powierzchni substratów w tym właściwości elektrokinetycznych powierzchni oraz monowarstw nanocząstek i makrojonów z użyciem metody potencjału przepływu.

Doctor of chemical sciences since 2014. Adjunct in Jerzy Haber Institute of Catalysis and Surface Chemistry, Polish Academy of Sciences. A graduate of uniform Master's studies at the Cracow University of Technology, Faculty of Chemical Engineering and Technology, a graduate of post-graduate studies at AGH University of Science and Technology (Biomaterials - Materials for Medicine). Head of the NCN project (Sonata) related to production of mon- and multilayers composed of nanoparticles with incorporated biomolecules: polyelectrolytes, polypeptides. The carried out research comprises the studies on both nanoparticle and macroion adsorption/desorption kinetics at/from solid/liquid interfaces. Coauthor in 35 publications and 1 patent. Extensive experience in conducting research using microelectrophoresis and DLS techniques to characterize bulk properties of macromolecules and nanoparticles as well as in conducting studies on the electrokinetic properties of mono- and multilayers deposited on the surface of solid substrates with the use of the streaming potential method.

Profesor Zbigniew Adamczyk - Profesor w Instytucie Katalizy i Fizykochemii Powierzchni im. Jerzego Habera PAN. Doktor nauk chemicznych (1978); doktor habilitowany (1986), profesor nauk chemicznych (1994). Tematyka badawcza: mechanizmy i kinetyka adsorpcji na powierzchniach międzyfazowych; stabilność układów koloidalnych i biokoloidalnych, oddziaływania elektrostatyczne w układach zdyspergowanych, zjawiska elektrokinetyczne, mikrohydrodynamika. Autor ponad 300 publikacji, w tym 30 prac przeglądowych, rozdziałów i książek min. Particles at Interfaces: Interactions, Deposition, Structure, Elsevier 2006, 2017, współautor 10 patentów. Osiagnięcia naukowe: uogólnienie teorii dyfuzji konwekcyjnej, rozwinięcie teorii randomalnej sekwencyjnej adsorpcji, sformułowanie nowego modelu teoretycznego zjawisk elektrokinetycznych, uogólnienie modelu Langmuira, ilościowy opis mikrohydrodynamiki makrojonów i białek globularnych, rozwinięcie nowych metod pomiarowych kinetyki adsorpcji białek w warunkach in situ. Edytor czasopisma Curr. Opin. Colloid Interface Sci., członek rady redakcyjnej czasopism: $A d v$. Colloid Interface Sci.; Colloids Surf. A, Colloids Surf. A; J Colloid Interface Sci. Członek Polskiej Akademii Umiejętności oraz American Chemical Society.

Professor at Jerzy Haber Institute of Catalysis and Surface Chemistry, Polish Academy of Sciences. Ph.D. in physical chemistry (1978); D.Sc. (Habilitation) in Chemistry (1986), Full Professor in Chemistry since 1994. Research interests: mechanisms and kinetics of macroion/proteins/nanoparticle adsorption; electrostatic interactions of macromolecules and nanoparticles; electrokinetic phenomena; microhydrodynamics of macroions and proteins. Author of over 300 publications comprising 30 review articles and chapters, 10 patents and books: Particles at Interfaces: Interactions, Deposition, Structure, Elsevier 2006, 2017. Main achievements: convective diffusion theory, hybrid model of protein adsorption, generalization of Langmuir isotherm, description of electrokinetic phenomena for heterogeneous surfaces, electrostatic effects in protein adsorption. Fellow of the Polish Academy of Arts and Sciences, Member of the American Chemical Society. Co-editor in Curr. Opin. Colloid Interface Sci. Member of the Editorial Boards: Adv. Colloid Interface Sci.; Colloids Surf. A, Colloids Surf. A; J Colloid Interface Sci. 


\begin{abstract}
Mechanisms of cationic macroion adsorption on negatively charged solid substrates comprising mica and silica were thoroughly discussed. Attention was focused on poly(allylamine hydrochloride) (PAH), poly(dimethyl-diallylammonium chloride) (PDDA) and poly-L-lysine (PLL) widely used in practice. The bulk physicochemical parameters controlling the macroion adsorption such as the diffusion coefficient, hydrodynamic diameter, intrinsic viscosity and electrophoretic mobility were discussed. The latter, experimentally accessible parameter, enables to determine the electrokinetic charge of macroion molecules, their isoelectric points and zeta potentials. On the other hand, the analysis of the hydrodynamic diameter and the intrinsic viscosity data confirmed a largely elongated shape of the molecules even for concentrated electrolyte solution. These results are used for a quantitative interpretation of macroion adsorption at solid substrates investigated using in situ streaming potential measurements. It is confirmed that the macroion mostly adsorb in the side-on orientation forming layers whose maximum coverage can be regulated by the ionic strength of the solution. This streaming potential method can also be used to determine the stability of the layers performing controlled desorption kinetic measurements. It is shown that at $\mathrm{pH} 7.4$ the PDDA and PLL macroions form stable layers on solid substrates, which can be used for an efficient immobilization of negatively charged macroions and bioparticles comprising protein molecules and viruses.
\end{abstract}

Keywords: adsorption of macroions; electrokinetic characteristics of macroions; PAH and PDDA adsorption; macroion layers on solid substrates, streaming potential measurements; zeta potential of macroion molecules

Słowa kluczowe: adsorpcja makrojonów; charakterystyka makrojonów; adsorpcja PAH i PDDA; warstwa makrojonów na powierzchniach ciał stałych; pomiary potencjału przepływu; potencjał zeta makrocząstek 


\section{ABBREVIATIONS AND SYMBOLS}

\begin{tabular}{|c|c|}
\hline$A_{v}$ & - Avogadro constant \\
\hline$B_{0}$ & - the blocking function \\
\hline $2 b_{c}$ & - the thickness of the channel \\
\hline$c_{c}$ & - the width of the channel \\
\hline$c_{p}$ & - mass concentration expressed in $\mathrm{mg} \mathrm{L}^{-1}$ \\
\hline$d_{c}$ & - the equivalent molecule diameter \\
\hline$d_{H}$ & - the hydrodynamic diameter \\
\hline$D$ & - diffusion coefficient \\
\hline$E_{s}$ & - the streaming potential \\
\hline $2 h$ & - the distance between the sheets or plates \\
\hline$k$ & - the Boltzmann constant \\
\hline$k_{c}$ & - the average mass transfer rate constant in the channel \\
\hline$K_{a}$ & - the equilibrium adsorption constant \\
\hline$l$ & - the length of the channel \\
\hline$L_{e}$ & - the contour length of the molecule \\
\hline LBL & - the layer-by-layer method \\
\hline$M_{w}$ & - the molar mass of the macroion \\
\hline$n_{p}$ & - the macroion number concentration \\
\hline$N_{\mathrm{p}}$ & - the surface concentration of adsorbed molecules \\
\hline$\Delta P$ & - the hydrostatic pressure difference \\
\hline PAH & - poly(allylamine hydrochloride) \\
\hline PDDA & - poly(dimethyl-diallylammonium chloride) \\
\hline PLL & - poly-L-Lysine \\
\hline$q$ & $\begin{array}{l}\text { - effective (electrokinetic) charge of a macroion } \\
\text { molecule }\end{array}$ \\
\hline$Q$ & - the volumetric flow rate of the solution \\
\hline$S_{g}$ & $\begin{array}{l}\text { - the characteristic cross-section area of the given } \\
\text { macroion molecule }\end{array}$ \\
\hline$t$ & - adsorption time \\
\hline$T$ & - the absolute temperature \\
\hline$V_{\infty}$ & - the linear flow rate in the channel \\
\hline$w_{\mathrm{p}}$ & - the macroion mass fraction \\
\hline$\zeta_{i}$ & - zeta potential of substrate surface \\
\hline$\Theta$ & - the dimensionless coverage of macroions \\
\hline$\lambda$ & - the aspect ratio parameter \\
\hline$\eta_{e}$ & - the supporting electrolyte viscosity \\
\hline$\eta_{r}$ & - the relative viscosity of the solution \\
\hline$[\eta]$ & - the intrinsic viscosity of the macroion molecule \\
\hline$\mu_{e}$ & - the electrophoretic mobility \\
\hline$\rho_{\mathrm{s}}$ & - the density of macroion solutions \\
\hline$\rho_{\mathrm{e}}$ & - the density of the pure electrolyte solution \\
\hline$\rho_{p}$ & - the macroion density \\
\hline$\Phi_{\mathrm{V}}$ & - the macroion volume fraction \\
\hline
\end{tabular}




\section{INTRODUCTION}

Macroions commonly referred to as polyelectrolytes, are charged polymer macromolecules whose repeating units acquire an electric charge upon dissolving in polar solvents such as water. According to these charged groups, they can be divided into polycations or polyanions. Recently, macroions have been extensively studied due to a number of potential applications in many industrial processes, such as filtration, water treatment, papermaking, food manufacturing, mineral extraction etc. [1-5]. In those processes, they are widely used as thickeners, emulsifiers, flocculants, and conditioners [6]. Moreover, modification of solid substrates by macroions is of great significance to many practical and natural processes such as formation of nanocoatings on textiles [7], nano-encapsulation for controlled drug delivery and release [8-10], cell adhesion [11] or protein and enzyme immobilization and separation $[12,13]$.

Due to the growing applications of macroions, especially in medicine, many techniques have been exploited to produce the monolayer and multilayer films of desired coverage and structure. Thin films have been fabricated using various techniques such as Langmuir-Blodgett or self-assembly. One of the most promising technique of surface modification using macroions was the layer-by-layer (LBL) assembly technique, developed by Decher et. al, which has become a powerful tool for fabricating thin materials (nano - and microcapsules) with precise control of film composition and structure [14-18]. Thin mono and multi-layer macroion films are of interests for the development of biocompatible materials for medical applications.

In this work we describe investigations concerning three types of macromolecules: poly(allylamine hydrochloride) (PAH), the poly(diallyldimethylammonium chloride) (PDDA), and the polypeptide poly-L-lysine (PLL) (a naturally-occurring aminoacid). PAH as well as PDDA belong to the group of macroions comprising hydrophilic, positively charged ammonium groups. Both are water-soluble, which make them attractive for biological applications due to the environmental-friendly behavior. PAH has been extensively used as a cationic component of multilayers for controlled drug delivery [19,20], cell adhesion [21] macroion or antibodies and enzymes immobilization and separation [22]. The strong PDDA macroion was initially used in order to produce the paper exhibiting a large electroconductivity [23]. Presently, it is commonly used for effective separation of biomolecules [24], protein immobilization [25] and removal of bacteria from sludge [26]. In the group of polypeptides, PLL comprises amino groups, which can be easily protonated over a broad $\mathrm{pH}$ range [22] and assumes three types of conformations, i.e., $a$-helix, $\beta$-sheet, and random coil [27]. Due to the variety of secondary structures and controlled conformational transitions 
among these structures, PLL is widely used as a building block of novel materials for medical applications, e.g., drug transport [28], microencapsulation of islets [29,30], cells [31,32] and chromosome preparations [33]. In addition, PLL has been used in biomimetic mineralization [34], cell attachment [35], biosensors, and biosensor arrays [36].

One can argue that surface modification procedures adopted in these applications could be better controlled and optimized if the mechanisms of macroion adsorption at solid substrates were elucidated. This primarily requires valid information about various physicochemical parameters characterizing macroion molecule properties. Therefore, in this work such experimental data are collected and thoroughly analyzed. Bulk physicochemical parameters for controlling the macroion adsorption such as the molecule conformation, diffusion coefficient, electrokinetic charge, zeta potential and intrinsic viscosity are discussed. These data are used for a quantitative interpretation of macroion adsorption investigated using in situ experimental techniques. It is underlined that the macroion adsorb mostly in the side-on orientation forming layers whose maximum coverage can be regulated by the ionic strength of the supporting electrolyte. On the other hand, the macroion desorption experiments enable to quantitatively asses the stability of the layers on solid substrates. Such layers of well controlled coverage can be used for an efficient immobilization of negatively charged bioparticles comprising protein molecules and viruses [37].

\section{EXPERIMENTAL METHODS}

The density of macroin molecules was experimentally determined by the solution dilution method as described in Refs. [38,39]. Firstly, the density of macroion solutions in an electrolyte of a fixed ionic strength $\rho_{\mathrm{s}}$ is measured by a densitometer as a function of the macroion mass fraction $w_{\mathrm{p}}$. Then, the experimental dependence of $\rho_{\mathrm{e}} / \rho_{\mathrm{s}}$ on $w_{\mathrm{p}}$ (where $\rho_{\mathrm{e}}$ is the density of the pure electrolyte solution) is fitted by a straight with the slope $s_{\rho}$. Finally, the macroion molecule density $\rho_{p}$ is calculated from the following formula:

$$
\rho_{\mathrm{p}}=\frac{\rho_{\mathrm{e}}}{1+S_{\mathrm{p}}}
$$

The viscosity of macroion solutions $\eta_{p}$ of defined concentrations is measured using capillary viscometers, comprising the Cannon-Ubbelohde semi-micro dilution device [39,40], which requires small amounts of macroion solution (typically $5 \mathrm{~mL}$ ) and permits easy serial dilutions. The set-up is equipped with a thermostat that 
allowed a precise control of temperature during the measurement, which are carried out for very low range of macroion concentration, usually equal to $50-500 \mathrm{mg} \mathrm{L}^{-1}$ $[38,39]$. Then, the relative viscosity of the solution $\eta_{r}=\eta_{p} / \eta_{e}$ (where $\eta_{e}$ is the supporting electrolyte viscosity) is plotted against the macroion volume fraction $\Phi_{\mathrm{V}}=w_{p} / \rho_{p}$. The slope of this dependence corresponds to the intrinsic viscosity of the macroion molecule denoted as $[\eta]$.

The electrophoretic mobility and the diffusion coefficients of macroion molecules under various conditions were determined by the electrophoretic measurements (Laser Doppler Velocimetry (LDV) technique) and the dynamic light scattering (DLS) using the Malvern Zetasizer Nano ZS apparatus [39,41,42]. Knowing the electrophoretic mobility one can calculate the electrokinetic charge per macroion molecule and its zeta potential.

On the other hand, using the diffusion coefficient, $D$, one can determine the hydrodynamic diameter of molecules using the Stokes-Einstein relationship [43]:

$$
d_{H}=\frac{k T}{3 \pi \eta_{e} D}
$$

where $d_{H}$ is the hydrodynamic diameter, $k$ is the Boltzmann constant and $T$ is the absolute temperature.

Zeta potentials of bare and macroion covered solid substrates (mica, silicon/silica wafers) were determined via streaming potential measurements using a four-electrode the microfluidic cell $[44,45]$. The main part of the cell was a parallel plate channel formed by mica sheets or silicon plates separated by a perfluoroethylene spacer. The streaming potential $E_{s}$ was measured using a pair of $\mathrm{Ag} / \mathrm{AgCl}$ electrodes as a function of the hydrostatic pressure difference $\Delta P$, driving the electrolyte flow through the channel. The overall cell electric conductivity $K_{e}$ was determined using a pair of platinum electrodes. Knowing the slope of the $E_{s}$ vs. $\Delta P$ dependence, the apparent zeta potential of substrate surface $\left(\zeta_{i}\right)$ was calculated from the Smoluchowski formula [46]:

$$
\zeta_{i}=\frac{\eta K_{e}}{\varepsilon}\left(\frac{\Delta E_{s}}{\Delta P}\right)
$$

where $\eta$ is the dynamic viscosity of the solution, $\varepsilon$ is the dielectric permittivity. The correction for the surface conductance is about $2 \%$ for ionic strength of $I=10^{-3} \mathrm{M}$ and becomes negligible for larger ionic strength [44,45,47]. 


\section{BULK MACROION CHARACTERISTICS}

As mentioned, the results obtained for the following macroions are discussed in this work: poly(allylamine hydrochloride) PAH [41], poly(diallyldimethylammonium chloride) (PDDA) $[38,41]$ and the polypeptide poly-L-lyzine (PLL) bromide $[39,48]$. The macroion monomer chemical structures, with their molar masses and molecule conformations in electrolyte solutions are collected in Table 1.

Table 1. Monomer chemical structures with their molar masses and molecule conformation derived from molecular dynamics (MD) modeling [39,42,49]

\begin{tabular}{|c|c|c|c|}
\hline Macroion & PAH & PDDA & PLL \\
\hline $\begin{array}{l}\text { Monomer } \\
\text { chemical } \\
\text { structure }\end{array}$ & $\mathrm{CH}_{2}-\mathrm{CH}$ & [42] & [39] \\
\hline $\begin{array}{c}\text { Monomer molar mass, } \\
\mathrm{kg} \mathrm{mol}^{-1}\end{array}$ & $\begin{array}{c}0.093 \\
\text { Ref. [49] }\end{array}$ & $\begin{array}{c}0.162 \\
\text { Ref. }[42 \\
\end{array}$ & $\begin{array}{c}0.209 \\
\text { Refs. }[50,39]\end{array}$ \\
\hline $\begin{array}{l}\text { Molecule conformation } \\
\text { from MD modeling }\end{array}$ & Ref. [49] & $\begin{array}{r}\text { Ref. [42 } \\
\text { Rent }\end{array}$ & 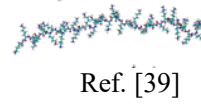 \\
\hline
\end{tabular}

It is interesting to mention that the theoretical modeling results described in Refs. [38,39,42,49] confirm that all macroion molecules exhibit an elongated, flexible rod shape in electrolyte solutions for ionic strength up to $0.15 \mathrm{M}$.

On the other hand, the main physicochemical parameters characterizing these macroions determined in Refs. [39,41,42,49] are collected in Table 2.

It should be mentioned that among these parameters, the electrophoretic mobility $\mu_{e}$, which can be directly measured by the LDV technique, is of essential significance serving as a generic parameter for calculations of the zeta potential and the effective charge of macroion molecules. These parameter governs macroion solutions stability and molecule interactions with substrate surfaces enabling their adsorption. Therefore, in this section the electrophoretic mobility and zeta potential data available in the literature are presented and discussed in some detail. 
Table 2. Physicochemical properties of macroions $[39,41,42,48]$

\begin{tabular}{|c|c|c|c|}
\hline Macroion & PAH & PDDA & PLL \\
\hline Quantity, Unit & $\begin{array}{c}0.7 \times 10^{2} \\
\text { Refs. [41,48] }\end{array}$ & $\begin{array}{c}1.0-1.6 \times 10^{2} \\
\text { Refs. [42,48] }\end{array}$ & $\begin{array}{c}0.75-1.9 \times 10^{2} \\
\text { Ref. [39] }\end{array}$ \\
\hline Molar mass, $\mathrm{kg} \mathrm{mol}^{-1}$ & $\begin{array}{c}1.15 \times 10^{3} \\
\text { Ref. [49] }\end{array}$ & $\begin{array}{c}1.16 \times 10^{3} \\
\text { Ref. [38] }\end{array}$ & $\begin{array}{c}1.60 \times 10^{3} \\
\text { Ref. [39] }\end{array}$ \\
\hline Density, kg m ${ }^{-3}$ & $1.5 \times 10^{-7}$ & $1.4 \times 10^{-7}$ & $2.0 \times 10^{-7}$ \\
\hline Diffusion coefficient, $\mathrm{m}^{2} \mathrm{~s}^{-1}$ & 33 & 32 & 24 \\
\hline Hydrodynamic diameter, nm & 3.6 & 2.8 & 3.5 \\
\hline Electrophoretic mobility, & 63 & 46 & 44 \\
\hline Number of uncompensated charges, 1 & 68 & 54 & 63 \\
\hline Zeta potential, mV & - & 568 & 305 \\
\hline Intrinsic viscosity, 1 & & & \\
\hline
\end{tabular}

Footnotes: $0.01 \mathrm{M} \mathrm{NaCl}, \mathrm{pH} 5.6, T=298 \mathrm{~K}$

In Fig. 1 the dependence of the electrophoretic mobility measured as a function of $\mathrm{pH}$ for various ionic strengths is presented for the three maroions: PAH, PDDA and PLL, respectively.

One can observe in Fig. 1 that the electrophoretic mobility of all macroions is positive for a broad $\mathrm{pH}$ range and ionic strength up to $0.15 \mathrm{M}$. However, at $\mathrm{pH}$ larger than 8 , the electrophoretic mobility of PAH and PLL abruptly decreases and vanishes at $\mathrm{pH}$ equal to 10 and 9.5 , respectively. These $\mathrm{pH}$ values can be identified as the isoelectric point (IEP) of these macroions [51-53]. In the case of PDDA its electrophoretic mobility remains positive for $\mathrm{pH}$ up to 11 , hence the molecules exhibit no IEP. This can be attributed to the fact that its charge is generated due to the presence of the quaternary ammonium ionic groups [38,54,55].

Using the electrophoretic mobility data one can calculated the zeta potential of molecules using the Henry formula [56]. Dependencies of the macroion zeta potential on $\mathrm{pH}$ for various ionic strengths acquired in this way are presented in Fig. 2. As can be seen, analogously to the electrophoretic mobility, the zeta potential remains positive for a broad $\mathrm{pH}$ range and ionic strength up to $0.15 \mathrm{M}$.

At $\mathrm{pH} 5.6$ and ionic strength of $10^{-2} \mathrm{M}$ the zeta potential is equal to 68,54 and $63 \mathrm{mV}$, for PAH, PDDA and PLL molecules, respectively. At pH 7.4 and the same ionic strength the zeta potential slightly decrease to 62,53 and $58 \mathrm{mV}$, for PAH, PDDA and PLL molecules, respectively. 

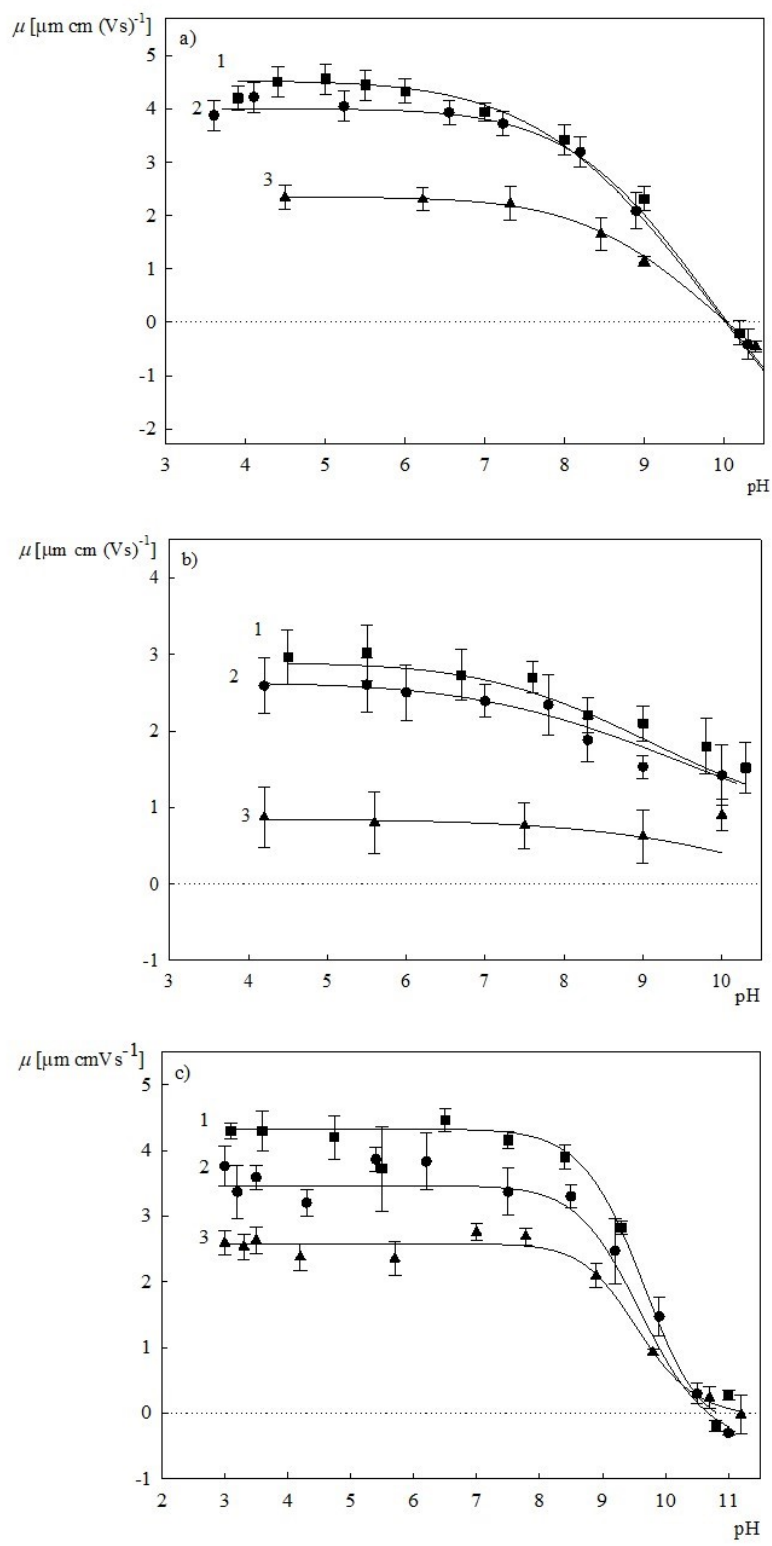

Figure 1. The dependence of the electrophoretic mobility on $\mathrm{pH}$ experimentally determined (LDV) for the following macroions :

a) PAH: 1) (•) $\left.\left.I=10^{-3} \mathrm{M}, 2\right)(\bullet) I=10^{-2} \mathrm{M}, 3\right)(\boldsymbol{\Delta}) I=0.15 \mathrm{M}$

b) PDDA: 1) (•) $\left.\left.I=10^{-3} \mathrm{M}, 2\right)(\bullet) I=10^{-2} \mathrm{M}, 3\right)(\mathbf{\Delta}) I=0.15 \mathrm{M}$

c) PLL: 1) 1) (•) $\left.\left.I=10^{-3} \mathrm{M}, 2\right)(\bullet) I=10^{-2} \mathrm{M}, 3\right)(\mathbf{\Delta}) I=0.15 \mathrm{M}$

The solid lines represent nonlinear interpolations of experimental data $[38,39,41,48,49]$ 
Additionally, using the electrophoretic mobility and the hydrodynamic diameter data one can calculate the effective (electrokinetic) charge of a macroion molecule $q$ from the Lorentz - Stokes relationship [57]:

$$
q=\frac{k T}{D} \mu_{e}=3 \pi \eta d_{H} \mu_{e}
$$

It is convenient to express $q$ in terms the average number of elementary charges per molecule considering that it is equal to $1.602 \times 10^{-19} \mathrm{C}$. Such results were extensively discussed in Refs. [41,57-59]. It was calculated that for the standard conditions of $10^{-2} \mathrm{M} \mathrm{NaCl}, \mathrm{pH} 5.6, T=298 \mathrm{~K}$, the number of positive charges per molecule was equal to 63,46 , and 44 for PAH, PDDA and PLL, respectively. It should be mentioned that the presence of positive charges on the macroion molecules creates favorable conditions for electrostatically driven adsorption at negatively charged substrates.

It is also useful to analyze the intrinsic viscosity data collected for macroions, which provide insight into the molecule conformations and shape under various physicochemical conditions. As can be inferred from the data shown in Table 2, the intrinsic viscosity of PDDA and PLL for $10^{-2} \mathrm{M}$ ionic strength (pH 5.6) exceeds by orders of magnitude the Einstein value pertinent to spheres, equal to 2.5. At lower ionic strength these values are significantly larger reaching 1797 and 870 for $10^{-3} \mathrm{M}$ for PDDA and PLL, respectively $[38,39,42]$. This confirms that the macroion molecules assume extended conformations in accordance with theoretical MD modeling. As shown in Ref. [60] this corresponds to the slender body hydrodynamic regime where it is predicted that the intrinsic viscosity only depends on the aspect ratio parameter $\lambda$ equal to $L_{e} / d_{c}$ ( $L_{e}$ is the contour length of the molecule and $d_{c}$ is the equivalent molecule diameter $d_{c}$ ). Analogously, it is shown that the hydrodynamic diameter of a molecule under the slender body regime only depends on the aspect ratio parameter. Therefore, using the experimental values of the intrinsic viscosity and the hydrodynamic diameter one can determine the molar mass of a macroion with a precision unprecedented by other methods [61]. Moreover, knowing the contour length and the diameter of the molecule one can predict its cross-section area in the side-on orientation assuming its flexible cylinder shape. This parameter facilitates a proper interpretation of macroion adsorption experiments discussed below. 

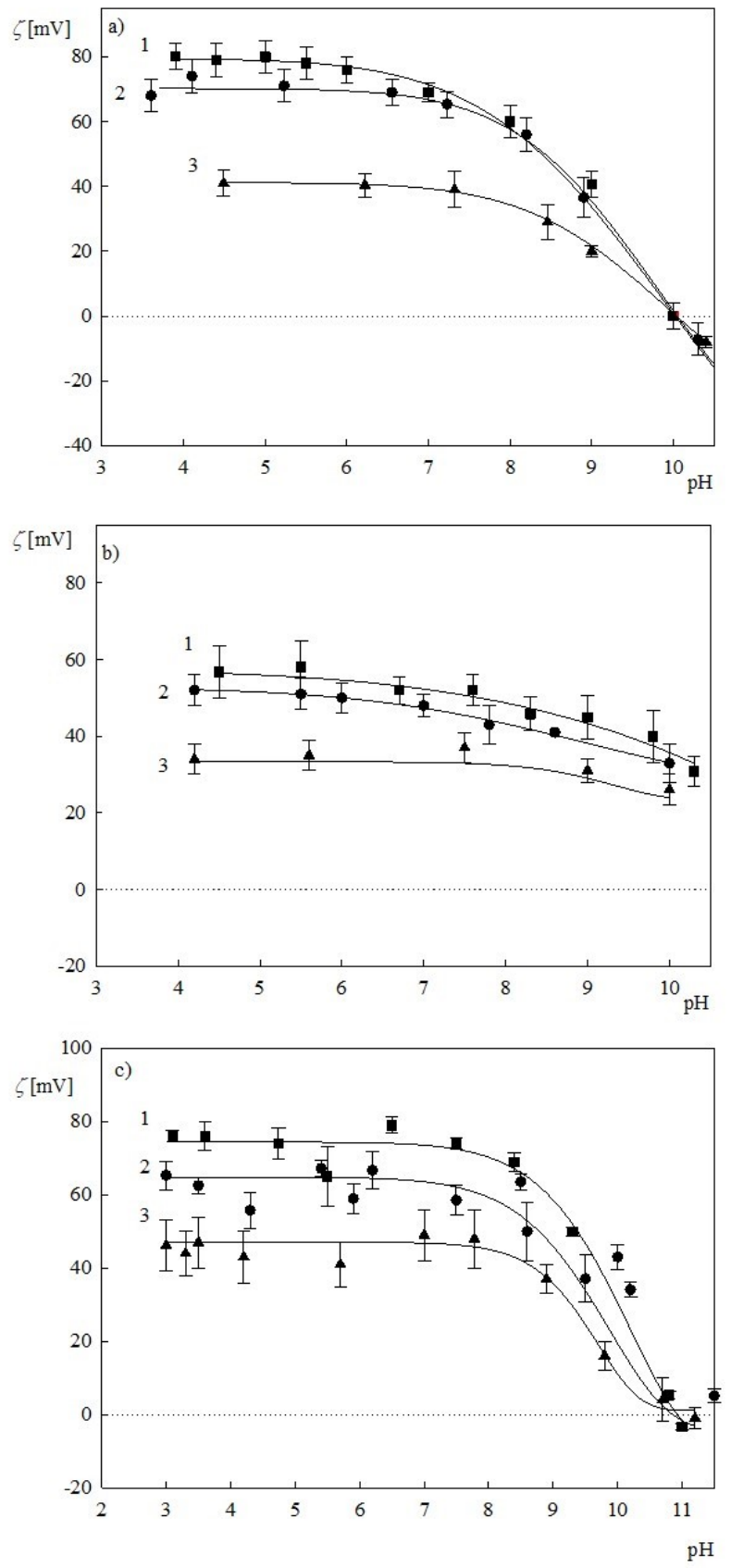

Figure 2. The dependence of the zeta potential (calculated using the Henry formula ) on $\mathrm{pH}$ for the following macroions :
a) PAH: 1) (•) $\left.\left.I=10^{-3} \mathrm{M}, 2\right)(\bullet) I=10^{-2} \mathrm{M}, 3\right)(\mathbf{\Delta}) I=0.15 \mathrm{M}$
b) PDDA: 1) (•) $\left.\left.I=10^{-3} \mathrm{M}, 2\right)(\bullet) I=10^{-2} \mathrm{M}, 3\right)(\boldsymbol{\Delta}) I=0.15 \mathrm{M}$
c) PLL: 1) (•) $\left.\left.I=10^{-3} \mathrm{M}, 2\right)(\bullet) I=10^{-2} \mathrm{M}, 3\right)(\boldsymbol{\Delta}) I=0.15 \mathrm{M}$

The solid lines represent nonlinear interpolations of experimental data $[41,48]$ 


\section{MACROION ADSORPTION - MONOLAYER CHARACTERISTICS}

The adsorption kinetics of macroions was investigated by the streaming potential method according to the above described procedure for two model substrates: mica and silicon/silica wafers. Both substrates exhibit exceptionally homogeneous surface properties and are characterized by a small rms factor equal to 0.1 and $0.15 \mathrm{~nm}$, respectively Ref. [unpublished data].

The dependence of the zeta potential of these substrates on $\mathrm{pH}$ calculated using the Smoluchowski formula is shown in Fig. 3 for $I=10^{-2} \mathrm{M} \mathrm{NaCl}$. It can be seen that the bare mica surface is characterized by a negative zeta potential decreasing from -42 to -72 for $\mathrm{pH} 3.5$ and 7.4 , respectively. The zeta potential for silicon/silica is less negative and varies between -16 to -57 for $\mathrm{pH} 3.5$ and 7.4 , respectively. It is interesting to mention that these values correspond to the electrokinetic charge density of mica equal to $-0.121,-0.139$ elementary charges per square nanometer at pH 3.5 and 7.4, respectively. For the silicon/silica substrate one obtains -0.028 and -0.104 per square nanometer at $\mathrm{pH} 3.5$ and 7.4 , respectively.

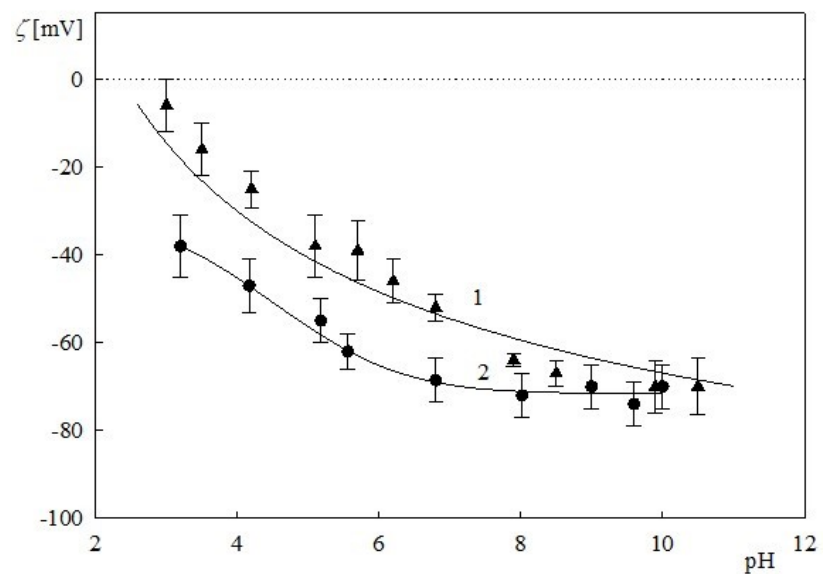

Figure 3. The $\mathrm{pH}$ dependence of the zeta potential of bare substrates used in the macroion adsorption experiments determined by the streaming potential measurements, $I=10^{-2} \mathrm{M}$.

1. ( $\boldsymbol{\Delta})$ silicon $/ \mathrm{SiO}_{2}$ wafers

2. (•) mica sheet

The solids lines represent nonlinear interpolations of experimental data 
Macroion layers of controlled coverage were formed at such thoroughly determined substrates according to three different methods as described in Refs. $[41,62,63]$. First method was the diffusion-controlled adsorption, where the macroion adsorption was carried out directly in the electrokinetic cell for an appropriate period of time (typically 2-30 minutes) and for the solution concentration ranging from $1-5 \mathrm{mg} \mathrm{L}^{-1}$. The second method was also based on the diffusion-controlled adsorption, but in this case, the macroion adsorption was carried out ex situ. Accordingly, two mica sheets or silicon/silica plates were placed into the thermostated diffusion cell, and kept within suitable period of time, usually up to $30 \mathrm{~min}$. Then, the macroion-covered substrates were flushed with pure water, to remove non-bonded molecules, and placed in the electrokinetic cell in order to perform the streaming potential measurement. The coverage of macroion was calculated considering the diffusion-controlled transport from finite volumes, for which the adsorption kinetics is governed by the equation [64]:

$$
N_{p}=h\left[1-\frac{8}{\pi^{2}} \sum_{i=1}^{\infty} \frac{e^{-\frac{(2 i-1)^{2} \pi^{2} D_{p}}{4 h^{2}} t}}{(2 i-1)^{2}}\right] n_{p}
$$

where: $N_{\mathrm{p}}$ is the surface concentration of adsorbed molecules, $2 h$ is the distance between the sheets or plates, $t$ is adsorption time, $n_{p}$ is the macroion number concentration, connected with the mass concentration expressed in $\mathrm{mg} \mathrm{L}^{-1}$ and denoted as $c_{p}$, expressed by the following relationship :

$$
n_{p}=10^{-6} c_{p} \frac{A_{v}}{M_{w}}
$$

where $A_{v}=6.023 \times 10^{23}$ is the Avogadro constant and $M_{w}$ is the molar mass of the macroion.

In the case of the third method, the macroion adsorption was carried out in situ under convection-controlled transport. For such convection-controlled adsorption regime the surface concentration of molecules is given by:

$$
N_{p}=k_{c} n_{p} t
$$

where $k_{c}$ is the average mass transfer rate constant in the channel. This parameter can be calculated ab initio for a concrete cell geometry (in the form of a parallel-plate channel) from the following formula $[64,65]$ :

$$
k_{c}=1.165 \frac{V_{\infty}^{1 / 3} D^{2 / 3}}{b_{c}^{1 / 3} l^{1 / 3}}
$$


where $V_{\infty}=Q / 4 b_{c} c_{c}$ is the linear flow rate in the channel, $Q$ is the volumetric flow rate of the solution, $2 b_{c}$ is the thickness of the channel, $c_{c}$ is the width and $l$ is the length of the channel.

Eq. (7) indicates that the mass transfer for a fixed channel dimensions only depends on the volumetric flow rate and the diffusion coefficient of a macroion.

However, it should be mentioned that Eqs. $(5,6)$ are only valid for not too large range of macroion coverage where surface blocking effects are not significant. Otherwise the true macroion coverage is calculated from numerical solutions of the mass transfer equation with the blocking function derived from the random sequential adsorption model [63].

It is experimentally confirmed in Ref. [41] that the diffusion-controlled adsorption, carried out directly in the experimental cell is the most convenient for a controlled formation of macroion layers because it allows to determine their electrokinetic properties without changing the measurements conditions. Moreover, the layers adsorbed under diffusion transport are more uniform and the usage of macroion solutions is much lower compared to the convection-controlled adsorption. However, the convection-driven transport conditions are advantageous for efficiently performing macroion desorption experiments as described in the next section.

Representative results obtained for these three macroions using the streaming potential method are shown in Figs. $4 \mathrm{a}-\mathrm{c}$, as the dependence of the zeta potential (calculated using the Smoluchowski formula) on the surface concentration $N_{p}$ calculated from Eq. (5). As can be seen, in all cases the initially negative zeta potential rapidly increases with $N_{p}$, attaining positive values for $N_{p}$ above $6 \times 10^{2} \mu \mathrm{m}^{-}$ ${ }^{2}$. Afterward, the zeta potential attains plateau values, which are markedly lower than the bulk zeta potentials of macroions. In order to theoretically interpret these experimental runs it is useful to introduce the dimensionless coverage of macroions defined as $[41,64,65]$ :

$$
\Theta=N_{p} S_{g}
$$

where $S_{g}$ is the characteristic cross-section area of the corresponding macroion molecule in the side-on orientation, which was equal to 155,110 and $118 \mathrm{~nm}^{2}$ for PAH, PDDA and PLL, respectively $[48,62]$. 

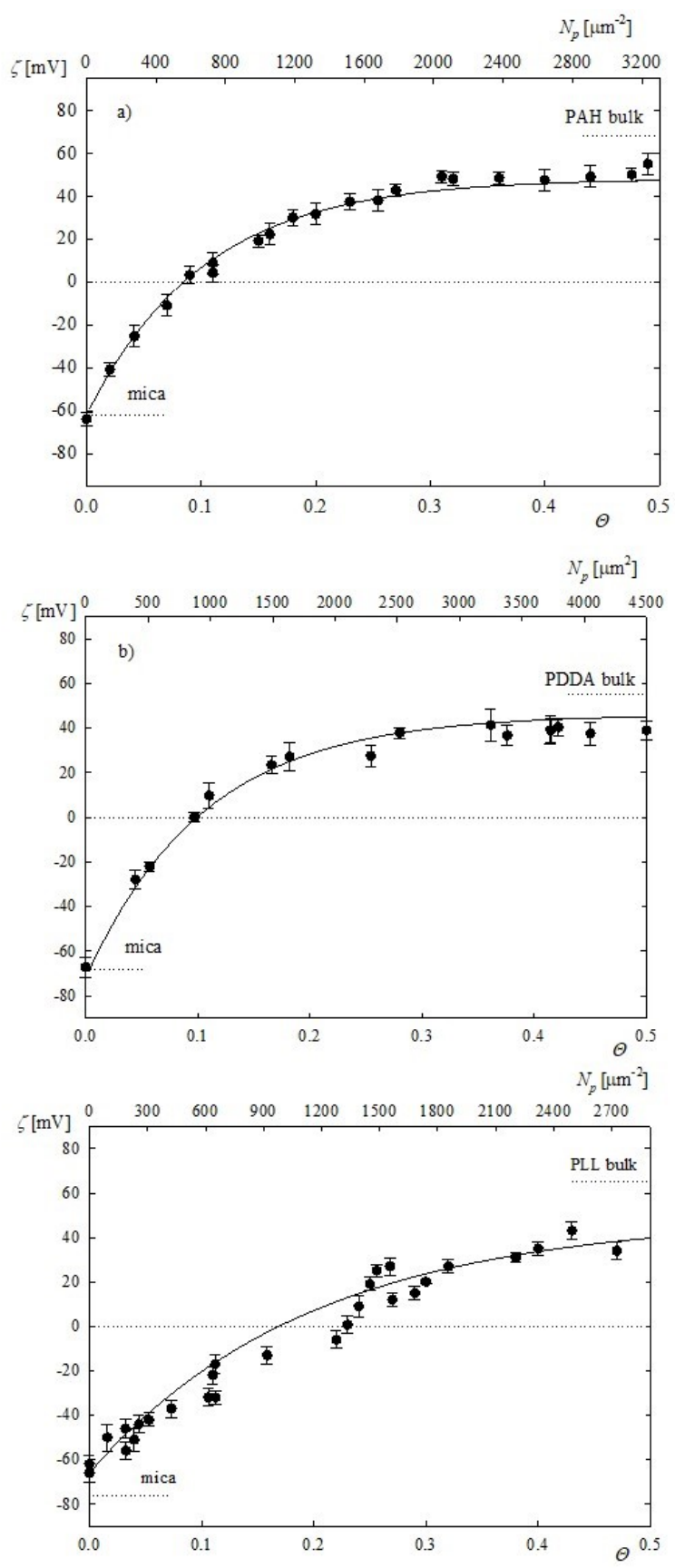

Figure 4. The dependence of the zeta potential of mica $\zeta$ on the coverage of macroions. The points denote experimental results obtained from the streaming potential measurements for $\mathrm{pH} 5.6$, $I=10-2$ M. a) PAH, b) PDDA, c) PLL. The solid lines denote exact theoretical results calculated from the $3 \mathrm{D}$ electrokinetic model, Eqs. $(9,10)$ 
Upon defining the coverage one can calculate the zeta potential of macroion covered substrate using the electrokinetic model formulated in Ref. [64] where the following analytical expression was derived:

$$
\zeta(\Theta)=F_{i}(\Theta) \zeta_{i}+F_{p}(\Theta) \zeta_{p}
$$

where $\zeta(\Theta)$ is the zeta potential of the macroion covered substrate, $\zeta_{i}$ is the zeta potential of bare substrate, $\zeta_{p}$ is the zeta potential of the macroion in the bulk (shown in Fig. 2) and $F_{i}(\Theta), F_{p}(\Theta)$ are the dimensionless functions of the coverage and the electrical double-layer thickness. They can be approximated by the following analytical expressions:

$$
\begin{gathered}
F_{i}(\Theta)=e^{-C_{i} \Theta} \\
F_{p}(\Theta)=\frac{1}{\sqrt{2}}\left(1-e^{-\sqrt{2} C_{p} \Theta}\right)
\end{gathered}
$$

The $C_{i}, C_{p}$ constants were calculated in Ref. [64] using the multipole expansion method for model macromolecules in the form of touching beads.

As can be seen in Fig. 4, the theoretical results calculated from the above electrokinetic model assuming a side-on orientation of adsorbed molecules adequately describes the experimental data for all macroions.

It is interesting to mention that analogous trends were observed for other ionic strengths, $\mathrm{pHs}$ and for the silicon/silica substrate as shown in Refs. [48,63]. These extensive experimental measurements confirmed that the macroions efficiently adsorb at negatively charged substrates and form single layers whose coverage and structure can be regulated by their bulk concentration and the ionic strength of the solution.

Such macroion layers, well-characterized in respect to the molecule conformation and coverage, are prone to physicochemical characteristics, which are more efficient to perform than using bulk methods (for example the LDV method). Primarily one can conveniently determine the dependence of the layer zeta potential on $\mathrm{pH}$, which can yield the isoelectric point of a macroion. Such measurements were performed in Ref. [50] according to the following procedure: initially a macroion layer of the maximum coverage was adsorbed in the electrotokinetic under optimum conditions (typically at $\mathrm{pH} 4.0$ and $I=10^{-2} \mathrm{M}$ ). Afterward, the $\mathrm{pH}$ of the electrolyte was changed in a discrete manner up to $\mathrm{pH} 10.5$, by adding an appropriate amount of $\mathrm{NaOH}$ and keeping the ionic strength at a constant level. The streaming potential for a given $\mathrm{pH}$ was measured and the maroion layer zeta potential was calculated from the Smoluchowski formula.

The results shown in Fig. 5 confirm that it is feasible to perform thorough characteristics of macroion zeta potentials for various ionic strengths using a single 
layer pre-adsorbed on a solid substrate. Given that these measurements require orders of magnitude lower macroion amounts than the bulk measurements (LDV), this has practical implications, especially in the case of expensive macroions.
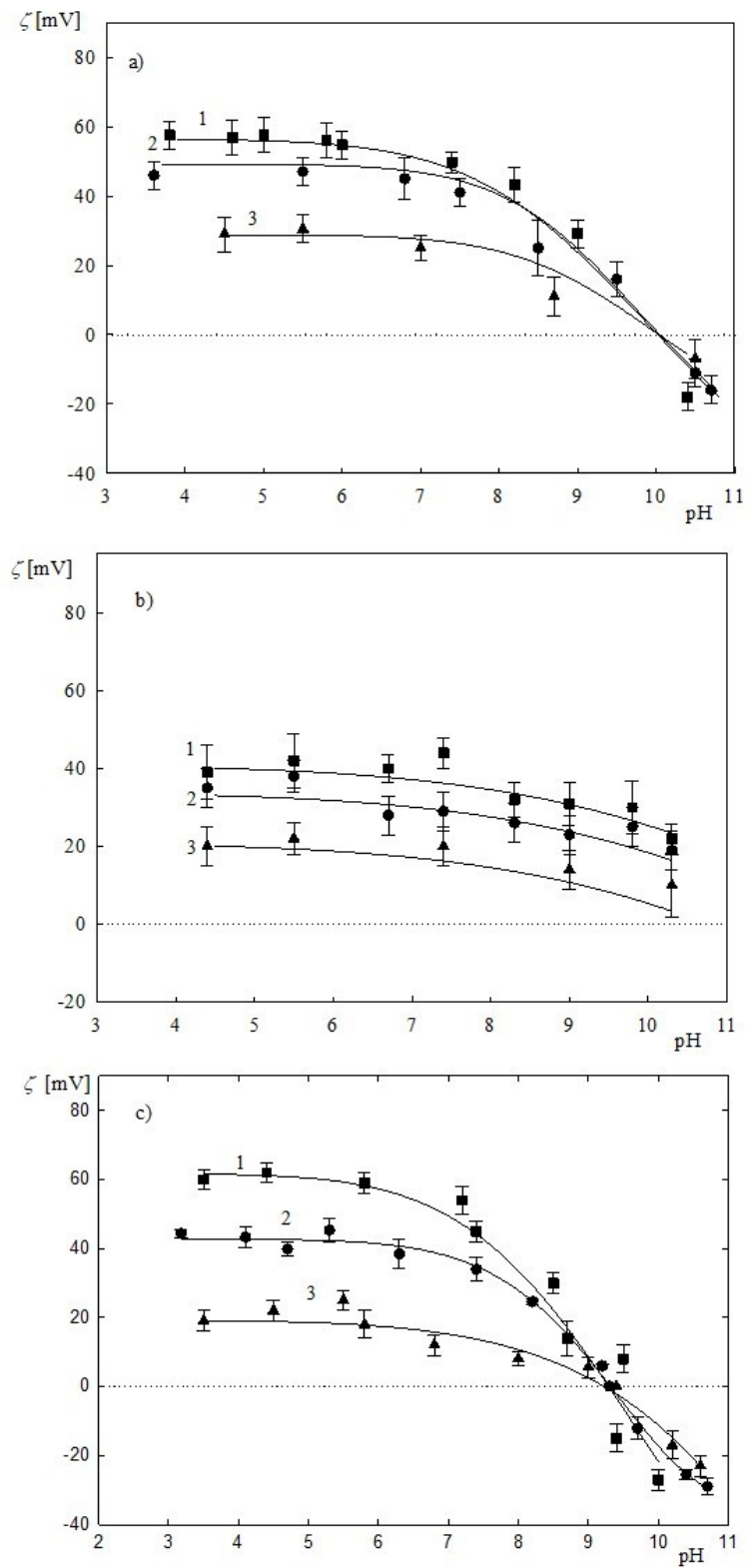

Figure 5. The dependence of the zeta potential of macroion layers on mica on $\mathrm{pH}$ determined by streaming potential measurements: 1) (ロ) $I=10-3 \mathrm{M}, 2)(\bullet) I=10-2 \mathrm{M}, 3)(\boldsymbol{\Delta}) I=0.15 \mathrm{M}$. a) PAH, b) PDDA, c) PLL. The solids lines represent nonlinear interpolations of experimental data 


\section{MACROION LAYER STABILITY}

The streaming potential measurements can also be used for a robust analysis of desorption kinetics, which furnishes quantitative information about the macroion layer stability. Such experiments were performed in Refs. [41,48,62] according to the following procedure: initially, macroion layer of controlled coverage was adsorbed in the cell and a fixed $\mathrm{pH}$ and ionic strength under diffusion conditions and the initial coverage of macroion was calculated from Eqs. $(5,7)$. Afterward, the channel was flushed with pure electrolyte of at a controlled volumetric flow rate (typically $0.035 \mathrm{~cm}^{3} \mathrm{~s}^{-1}$ ) at a fixed $\mathrm{pH}$ and ionic strength that can be different than during the layer adsorption stage. The streaming potential was measured for discrete time intervals with the entire run typically lasting 10 hours. In order to perform a quantitative analysis of the kinetic runs the zeta potential was converted to the macroion coverage using the transformed Eqs. (9-10) [57]:

$$
\Theta_{p}=\frac{1}{C_{i}} \ln \frac{\zeta_{i}-\zeta_{\infty}}{\zeta-\zeta_{\infty}}
$$

The kinetics of macroions' desorption acquired in this way for PBS buffer at pH 7.4 is shown in Fig. 6 [48].

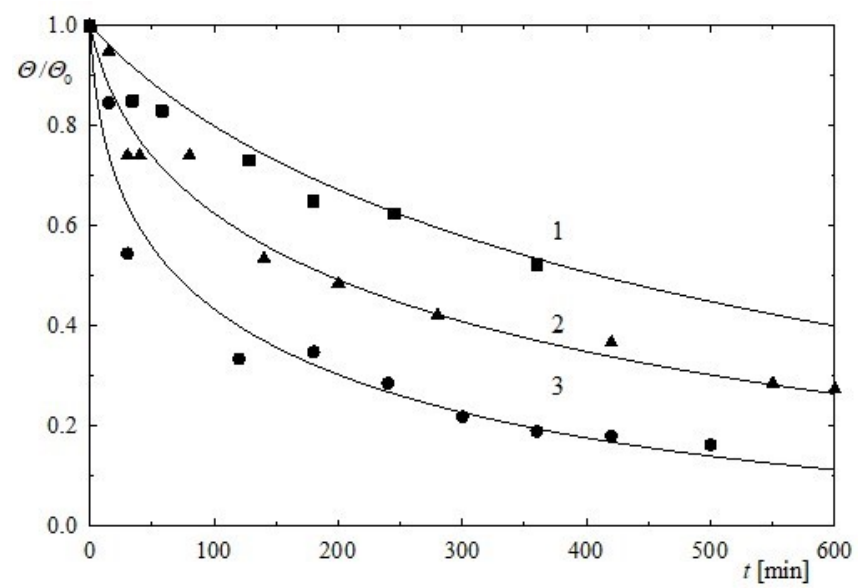

Figure 6. The kinetics of macroion desorption under flow conditions expressed as the dependence of the normalized layer coverage on the desorption time $t$ determined using the streaming potential

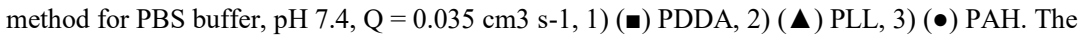
solid lines represent theoretical results calculated by numerical integration of Eq. (12) [48]

It can be seen that the differences in the desorption rate among macroions become more significant with the PDDA ion showing the largest and the PAH 
macroion the least stability. These experimental data were quantitatively interpreted in terms of the theoretical model discussed in Ref. [66]. The macroion adsorption/desorption kinetics under flow conditions can be predicted from the following formula:

$$
\int_{\Theta_{0}}^{\Theta} \frac{\left(k_{a}-k_{c}\right) B\left(\Theta^{\prime}\right)+k_{c}}{\Theta^{\prime}} d \Theta^{\prime}=-\left(k_{c} k_{a} / K_{a}\right) t
$$

where $k_{a}$ is the kinetic adsorption constant, $k_{c}$ is the bulk mass transfer constant calculated from Eq. (7) and $K_{a}$ is the equilibrium adsorption constant.

Because the $k_{a}$ constant can be calculated $a b$ initio using the diffusion coefficient of a molecule, the equilibrium adsorption constant for a macroion can be determined applying a non-linear fitting of experimental data using numerical solutions of Eq. (12). These constants determined in this way for these macroions at pH 7.4 are collected in Table 3.

It should be underlined that the above procedure for determining the equilibrium adsorption constant $K_{a}$ via the streaming potential measurements is more efficient than a direct determination via adsorption equilibrium measurements, which have to be carried out for very low bulk concentrations of macroion solutions and over an excessive desorption time.

Table 3. The adsorption constant $K_{a}[\mathrm{~cm}]$ for the PAH, PDDA and PLL macroions monolayers at mica determined using the streaming potential measurements (PBS buffer at $\mathrm{pH} 7.4$ ) [48]

\begin{tabular}{|l|l|}
\hline Macroion & $\boldsymbol{K}_{a}[\mathbf{c m}]$ \\
\hline PAH & 10.9 \\
\hline PLL & 27.1 \\
\hline PDDA & 62.5 \\
\hline
\end{tabular}

The equilibrium adsorption constants can also be used to predict the kinetics of macroion desorption under the diffusion-controlled transport regime. It was shown in Ref. [65] that the characteristic relaxation time of this process, defined as the time when the macroion coverage decreases to one half of its initial value, can be calculated from the formula:

$$
t_{d}=\frac{\pi}{4}(\ln 2)^{2} \frac{K_{a}^{2} B_{0}^{2}}{D}=0.377 \frac{K_{a}^{2} B_{0}^{2}}{D}
$$

where $B_{0}$ is the blocking function for $\Theta=\Theta_{0}$, which was calculated from the random sequential adsorption model. 
Eq. (13) indicates that the relaxation time is proportional to the square of the equilibrium adsorption constant and inversely proportional to the diffusion coefficient of macroion. Using the diffusion coefficient data given in Table 2, the $K_{a}$ values from Table 3 (for $\mathrm{pH} 7.4$ ) and assuming that $B_{0}=0.2$ one obtains from Eq. (13) that $t_{d}=1.3 \times 10^{7}, 5.5 \times 10^{7}$, and $4.5 \times 10^{8} \mathrm{~s}$ for PAH, PLL and PDDA, respectively. This corresponds to $3.6 \times 10^{3}, 1.5 \times 10^{4}$ and $1.3 \times 10^{5}$ hours. These desorption time under diffusion transport are practically infinite from an experimental point of view.

Considering the above discussed results one can argue that the cationic macroion layers can be exploited as an efficient platform for nanoparticle and bioparticle attachment investigations applying commonly used experimental techniques. For example in Refs. [67,68] the deposition of silver and gold nanoparticles at PAH modified silica sensors was studied using the quartz microbalance. This yielded reliable information about the absolute mass transfer coefficients and the range of applicability of this method. Analogously, in Ref. [37] the kinetics of virus attachment to PLL modified gold and silica sensors was investigated using the same technique.

\section{CONCLUSIONS}

It is shown that the streaming potential method is a useful tool for investigating in situ adsorption/desorption kinetics of macroion molecules at various solid/electrolyte interfaces. The interpretation of experimental data acquired in this way in terms of the electrokinetic model yields thorough physicochemical characteristics of macroion layers, especially their zeta potentials as a function of $\mathrm{pH}$ and molecule isoelectric points.

Additionally, the streaming potential measurements of desorption kinetics under flow conditions can be used to derive information about the stability of macroion layers, quantitatively characterized in terms of the equilibrium adsorption constants $K_{a}$. Such measurements are impractical using conventional approaches where adsorption equilibria are measured because this would require very low macroion concentration and in consequence excessive adsorption times.

Using the equilibrium adsorption constants it is shown that the macroion layers are stable under diffusion-controlled transport regime where in the case of PDDA the characteristic desorption time exceeds $1.3 \times 10^{5}$ hours.

Such cationic maroion layers can be exploited as an efficient platform for nanoparticle and bioparticle attachment and as supporting layers for the shell formation of microcapsules used for targeted drug delivery. 


\section{ACKNOWLEDGMENTS}

This work was financially supported by the Statutory activity of the J. Haber Institute of Catalysis and Surface Chemistry PAS.

\section{REFERENCES}

[1] E.M. Wilts, J. Herzberger, T.E. Long, Polym. Int., 2018, 67, 799.

L. Van Haver, S. Nayar, Algal Res., 2017, 24, 167.

[2] K.E. Bremmell, G.J. Jameson, S. Biggs, Colloids Surf. A, 1998, 139, 199.

[3] O.J. Rojas, P.M. Claesson, D. Muller, R.D. Neuman, J. Colloid Interface Sci., 1998, 205, 77.

[4] O.J. Rojas, R.D. Neuman, P.M. Claesson, J. Colloid Interface Sci., 2001, 237, 104.

[5] A. Toutianoush, B. Tieke, Mater. Sci. Eng. C, 2002, 22, 459.

[6] I. Popa, B.P. Cahill, P. Maroni, G. Papastavrou, M. Borkovec, J. Colloid Interface Sci., 2007, 309, 28.

[7] J. Junthip, N. Tabary, M. Maton, S. Ouerghemmi, J.N. Staelens, F. Cazaux, Ch. Neut, N. Blanchemain, B. Martel, Int. J. Pharm., 2020, 587, 119730.

[8] S.-Ch. How, Y.-F. Chen, P.-L. Hsieh, S. S. Wang, J.-S. Jan, Colloids Surf. B, 2017, 153, 244.

[9] C. Kirchner, A.M. Javier, A.S. Susha, A.L. Rogach, O. Kreft, G.B. Sükhorukov, W.J. Parak, Talanta, 2005, 67, 486.

[10] J. Gummel, F. Cousin, F. Boué, J. Am. Chem. Soc., 2007, 129, 5806.

[11] Y. Lu, J. Sun, J. Shen, Langmuir, 2008, 24, 8050.

[12] C.L. Cooper, P.L. Dubin, A.B. Kayitmazer, S. Turksen, Curr. Opin. Colloid Interface Sci., 2005, 10, 52 .

[13] N. Dizge, R. Epsztein, W. Cheng, C. J. Porter, M. Elimelech, J. Membr. Sci., 2018, 549, 357.

[14] G. Decher, J.D. Hong, J. Schmitt, Thin Solid Films, 1992, 210, 831.

[15] G. Decher, J.B. Schlenoff, Multilayer Thin Films: Sequential Assembly of Nanocomposite Materials, 1st ed., Wiley-VCH, Weinheim, 2003.

[16] L. Zhang, H. Chen, J. Sun, J. Shen, Chem. Mater., 2007, 19, 948.

[17] P.T. Hammond, Curr. Opin. Colloid Interface Sci., 1999, 4, 430.

[18] P.T. Hammond, Adv. Mater., 2004, 16, 1271.

[19] W. Jian, S. Xu, J. Wang, S. Feng, J. of App. Polym. Sci., 2013, 129, 2070.

[20] N. Reum, C. Fink-Straube, T. Klein, R.W. Hartmann, C.-M. Lehr, M. Schneider, Langmuir, 2010, 26, 16901.

[21] M.R. Kreke, A.S. Badami, J.B. Brady, R. Michael Akers, A.S. Goldstein, Biomaterials, 2005, 26, 2975.

[22] E.S. Forzani, V.M. Solís, E.J. Calvo, Anal. Chem., 2000, 72, 5300.

[23] M.F. Hoover, H.E. Carr, Tappi, 1968, 51, 552.

[24] I.-M. Hsing, Y. Xu, W. Zhao, Electroanalysis, 2007, 19, 755.

[25] Z.-P. Han, J. Fu, P. Ye, X.-P. Dong, Enzyme Microb. Tech., 2013, 53, 79.

[26] X. Zhao, Y. Zhang, Clean - Soil Air Water, 2013, 41, 37.

[27] T.-J. Yu, J.L. Lippert, W.L. Peticolas, Biopolymers, 1973, 12, 2161.

[28] L.M. Kaminskas, B.D. Kelly, V.M. McLeod, B.J. Boyd, G.Y. Krippner, E.D. Williams, C.J.H. Porter, Mol. Pharm., 2009, 6, 1190.

[29] H.A. Clayton, R.F.L. James, N.J.M. London, Acta Diabetol., 1993, 30, 181.

[30] P. de Vos, C.G. van Hoogmoed, J. van Zanten, S. Netter, J.H. Strubbe, H.J. Busscher, Biomaterials, 2003, 24, 305.

[31] F. Lim, R.D. Moss, J. Pharm. Sci., 1981, 70, 351. 
[32] X. Wang, W. Wang, J. Ma, X. Guo, X. Yu, X. Ma, Biotechnol. Prog., 2006, 22, 791.

[33] I.D. Dubé, C.J. Eaves, D.K. Kalousek, A.C. Eaves, Cancer Genet. Cytogen., 1981, 4, 157.

[34] W. Gao, B. Feng, Y. Ni, Y. Yang, X. Lu, J. Weng, Appl. Surf. Sci., 2010, 257, 538.

[35] B.R. Kranz, E. Thiel, S. Thierfelder, Blood, 1989, 73, 1942.

[36] M. Chittchang, H.H. Alur, A.K. Mitra, T.P. Johnston, J. Pharm. Pharmacol., 2002, 54, 315.

[37] A. Armanious, M. Aeppli, R. Jacak, D. Refardt, T. Sigstam, T. Kohn, M. Sander, Environ. Sci. Technol., 2016, 50, 732.

[38] A. Michna, Z. Adamczyk, K. Kubiak, K. Jamroży, J. Colloid Interface Sci., 2014, 428, 170.

[39] Z. Adamczyk, M. Morga, D. Kosior, P. Batys, J. Phys. Chem. C, 2018, 122, 23180.

[40] L. Ubbelohde, Ind. Eng. Chem. Anal. Ed., 1937, 9, 85.

[41] M. Morga, Z. Adamczyk, J. Colloid Interface Sci., 2013, 407, 196.

[42] Z. Adamczyk, K. Jamroży, P. Batys, A. Michna, J. Colloid Interface Sci., 2014, 435, 182.

[43] A. Einstein, Ann. Phys., 1910, 338, 1275.

[44] M. Zembala, Z. Adamczyk, Langmuir, 2000, 16, 1593.

[45] M. Zembala, Z. Adamczyk, P. Warszyński, Colloids Surf. A, 2001, 195, 3.

[46] M. Smoluchowski, Bull. Acad. Sci. Cracovie Classe Sci. Math. Natur. 1903, 1, 182.

[47] M. Zembala, Adv. Colloid Interface Sci., 2004, 112, 59.

[48] M. Morga, A. Michna, Z. Adamczyk, Colloids Surf. A, 2017, 529, 302.

[49] B. Jachimska, T. Jasiński, P. Warszyński, Z. Adamczyk, Colloids Surf. A, 2010, 355, 7.

[50] M. Morga, Z. Adamczyk, S. Gödrich, M. Oćwieja, G. Papastavrou, J. Colloid Interface Sci., 2015, 456, 116.

[51] A. Dos, V. Schimming, S. Tosoni, H.-H. Limbach, J. Phys. Chem. B, 2008, 112, 15604.

[52] S.E. Burke, C.J. Barrett, Biomacromolecules, 2003, 4, 1773.

[53] I. Dapić, D. Kovačević, Croat. Chem. Acta, 2011, 84, 185.

[54] I. Zhitomirsky, J. Appl. Electrochem., 2004, 34, 235.

[55] I. Zhitomirsky, Mater. Lett., 2004, 58, 420.

[56] Henry D. C., Lapworth Arthur, Proc. R. Soc. A Math. Phys. Eng. Sci., 1931, 133, 106.

[57] M. Dąbkowska, Z. Adamczyk, J. Colloid Interface Sci., 2012, 366, 105.

[58] Z. Adamczyk, M. Nattich, M. Wasilewska, M. Zaucha, Adv. Colloid Interface Sci., 2011, 168, 3.

[59] M. Morga, Z. Adamczyk, M. Oćwieja, J. Nanopart. Res., 2013, 15, 1.

[60] H. Brenner, Int. J. Multiph. Flow, 1974, 1, 195.

[61] Z. Adamczyk, M. Morga, D. Kosior, Sposób wyznaczania masy molowej polielektrolitów liniowych, zwłaszcza polilizyny, 2021, PL236792B1.

[62] M. Morga, Z. Adamczyk, D. Kosior, M. Kujda-Kruk, Langmuir, 2019, 35, 12042.

[63] D. Kosior, M. Morga, P. Maroni, M. Cieśla, Z. Adamczyk, J. Phys. Chem. C, 2020, 124, 4571.

[64] Z. Adamczyk, K. Sadlej, E. Wajnryb, M. Nattich, M.L. Ekiel-Jeżewska, J. Bławzdziewicz, Adv. Colloid Interface Sci., 2010, 153, 1.

[65] Z. Adamczyk, Particles at Interfaces: Interactions, Deposition, Structure, Elsevier, Amsterdam, 2017.

[66] M. Oćwieja, Z. Adamczyk, Langmuir, 2013, 29, 3546.

[67] K. Kubiak, Z. Adamczyk, M. Oćwieja, Langmuir, 2015, 31, 2988.

[68] M. Oćwieja, J. Maciejewska-Prończuk, Z. Adamczyk, M. Roman, J. Colloid Interface Sci., 2017, 501, 192.

Praca wpłynęła do Redakcji 7 czerwca 2021 r. 
